\title{
The Preparation and Properties of $\alpha$ and $\beta$ Pili from Variants of Neisseria gonorrhoeae P9
}

\author{
By PAUL R. LAMBDEN, * JANET N. ROBERTSON \\ AND PETER J. WATT \\ Department of Microbiology, Southampton University Medical School, South Laboratory \\ and Pathology Block, Southampton General Hospital, Southampton SO9 $4 X Y$
}

(Received 11 August 1980; revised 27 October 1980)

The $\alpha$ and $\beta$ type pili produced by variants of Neisseria gonorrhoeae P9 were isolated and characterized. The two types of pili showed clear differences in morphology, buoyant density $\left(\alpha, 1.292 \mathrm{~g} \mathrm{ml}^{-1} ; \beta, 1.282 \mathrm{~g} \mathrm{ml}^{-1}\right)$ and isoelectric point $(\alpha, \mathrm{pI} 5 \cdot 2 ; \beta, \mathrm{pI} 4 \cdot 3)$. Amino acid analysis of $\alpha$ and $\beta$ pili showed that their overall composition was similar with the exception that $\beta$ pili had a higher content of glutamate and alanine residues. A high degree of structural homology was seen in two-dimensional peptide maps of tryptic hydrolysates of $\alpha$ and $\beta$ pili. The molecular differences between $\alpha$ and $\beta$ pili were reflected in their antigenic activity and in their ability to attach to human cells. The binding of $\alpha$ pili to buccal epithelial cells was $\mathrm{pH}$ dependent with a maximum binding of $49 \%$ at $\mathrm{pH} 6 \cdot 5$, whereas the attachment of $\beta$ pili showed no $\mathrm{pH}$ optimum. The binding of pili to erythrocytes differed from binding to buccal epithelial cells in that attachment of both pili was identical with no $\mathrm{pH}$ optimum. Data from attachment of pili to human cells suggest that erythrocytes lack receptors for binding gonococcal pili.

\section{INTRODUCTION}

Pili, filamentous protein appendages extending some $5 \mu \mathrm{m}$ from the bacterial surface, are universally present on gonococci from fresh clinical isolates (Jephcott et al., 1971; Swanson et al., 1971). During non-selective subculture on laboratory media non-pilated variants soon outgrow the pilated gonococci indicating that growth within the host exerts a selective pressure favouring the pilated state.

Substantial amounts of data have accumulated demonstrating a role for pili in the attachment of gonococci to host cells (Swanson, 1973; James et al., 1976) and in impeding the phagocytosis of virulent gonococci by human polymorphonuclear leukocytes (Ofek et al., 1974; Dilworth et al., 1975). Despite this evidence of a common function for gonococcal pili the reported subunit molecular weights and amino acid compositions suggest significant structural variation in pili isolated from different strains (Robertson et al., 1977; Buchanan et al., 1978; Brinton et al., 1978). This was reflected in marked antigenic variation among the gonococcal pili. Further, the observation by Robertson and her colleagues (1977) that a minor pilus component isolated from Neisseria gonorrhoeae strain P9 differed in both isoelectric point and buoyant density from the major pilus component implied that a single strain of gonococcus could produce two distinct pilus types. Proof that a single strain of gonococcus could indeed elaborate two distinct types of pili came from studies with colony opacity variants of strain P9 (Lambden et al., 1980). These pili, designated $\alpha$ and $\beta$, differed in subunit molecular weight and in ability to attach to human buccal epithelial cells. Comparable differences in both subunit molecular weight and buoyant density of pili isolated from opaque and transparent variants of the same gonococcal strains have been 
demonstrated by Salit et al. (1980). In this report we present a detailed comparison of the physico-chemical properties of $\alpha$ and $\beta$ pili isolated from $N$. gonorrhoeae strain P9.

\section{METHODS}

Bacterial strains and growth conditions. Neisseria gonorrhoeae $\mathrm{P} 9$ variants were grown on clear typing medium as previously described (Lambden et al., 1979). Colonies of P9-2 ( $\alpha$ pili) and P9-20 ( $\beta$ pili) (Lambden et al., 1980) were picked, purified by repeated single colony isolation and stored in liquid nitrogen. Large-scale growth of organisms for the isolation of purified pili was performed in trays $(27 \times 38 \mathrm{~cm})$ of GC base (Difco) using the same supplement as that used in typing medium.

Preparation of pili. Gonococcal $\alpha$ and $\beta$ pili were purified essentially as described by Brinton et al. (1978). Organisms were grown on trays of $\mathrm{GC}$ base at $36{ }^{\circ} \mathrm{C}$ in an atmosphere of $5 \%(\mathrm{v} / \mathrm{v}) \mathrm{CO}_{2}$. The gonococci were harvested into ice-cold ethanolamine/ $\mathrm{HCl}(0.15 \mathrm{M}, \mathrm{pH} 10.5)$ and subjected to mild shearing in an Ultro-Turrax homogenizer (Vortex Mixers, Hampton, Middx) for $2 \mathrm{~min}$. The organisms were removed by centrifugation at $23000 \mathrm{~g}$ for $30 \mathrm{~min}$, and the pili were precipitated from the supernatant by adding saturated ammonium sulphate solution (made alkaline by the addition of 0.1 vol. of 10 -fold concentrated ethanolamine buffer) to give a final saturation of $10 \%$. Pili were recovered by centrifugation at $10000 \mathrm{~g}$ for $1 \mathrm{~h}$ and purified by further cycles of repeated disaggregation in ethanolamine buffer and precipitation with ammonium sulphate. Pili were finally washed in $2 \mathrm{M}-\mathrm{NaCl}$, resuspended in $1 \mathrm{M}-\mathrm{NaCl}$ and stored at $4{ }^{\circ} \mathrm{C}$ in $1 \mathrm{M}-\mathrm{NaCl}$ containing $8 \mathrm{~mm}$-sodium azide. The purity of the pilus preparation was checked by sodium dodecyl sulphate-polyacrylamide gel electrophoresis (SDS-PAGE) as described previously (Lambden et al., 1980).

Immunization. Rabbits were injected subcutaneously at several sites on the back with a total of $100 \mu \mathrm{g}$ of purified $\alpha$ or $\beta$ pili in incomplete Freund's adjuvant (Difco). The dose was repeated after 2, 4,6 and 8 weeks and the rabbits were bled 2 weeks after the last injection.

Dunkin Hartley guinea-pigs were injected intramuscularly with $100 \mu \mathrm{g}$ of $\alpha$ or $\beta$ pili in complete Freund's adjuvant (Difco). Two weeks later, $100 \mu \mathrm{g}$ of pili in incomplete Freund's adjuvant was injected at multiple intradermal sites and the animals were bled by cardiac puncture after a further 2 weeks.

Pilus agglutination assay. End-point dilution assays of antibody-mediated pilus agglutination were performed using the method of Brinton et al. (1978). Samples of $3 \mu \mathrm{l}$ of purified pili containing $500 \mu \mathrm{g}$ protein $\mathrm{ml}^{-1}$ in phosphate-buffered saline (PBS; Oxoid) pH 7.0 were mixed on microscope slides with $3 \mu \mathrm{l}$ of the appropriate antiserum dilution. After incubation for $1 \mathrm{~h}$ at $37^{\circ} \mathrm{C}$ in a moist chamber the slides were examined for pilus agglutination by dark-ground light microscopy using an Ortholux II microscope equipped with an oil immersion condenser (E. Leitz, Wetzlar, W. Germany).

Radioiodination of pili. ${ }^{125}$ I-labelled $\alpha$ and $\beta$ pili were prepared using chloramine-T and carrier-free $\mathrm{Na}^{125}$ ( The Radiochemical Centre, Amersham) (Greenwood et al., 1963). Pili (2 to $3 \mathrm{mg}$ ) in sodium phosphate buffer $(0.05 \mathrm{M}, \mathrm{pH} 7.5)$ were treated with chloramine-T $(0.5 \mathrm{mg})$ and $\mathrm{Na}^{125} \mathrm{I}(1 \mathrm{mCi} ; 37 \mathrm{MBq})$ in a total volume of $0.6 \mathrm{ml}$. After $5 \mathrm{~min}$ at room temperature the reaction was stopped by adding sodium metabisulphite $(1.25 \mathrm{mg})$ and potassium iodide $(2.5 \mathrm{mg})$. Pili were purified from other reaction products by repeated washing in $20 \%$ saturated ammonium sulphate. The specific activity of the ${ }^{125}$ I-lavelled pili was calculated by protein estimation and gamma counting (LKB Wallac 1280 ultrogamma) and was usually between 0.3 and $0.4 \mu \mathrm{Ci}$ ( $\mu \mathrm{g}$ protein) ${ }^{-1}[11$ to $15 \mathrm{kBq}(\mu \mathrm{g} \text { protein })^{-1} \mathrm{~J}$. The proportion of protein-bound ${ }^{125} \mathrm{I}$ was determined by precipitation with $7.5 \%(\mathrm{w} / \mathrm{v})$ trichloroacetic acid and was always greater than $98 \%$. The final iodination density was calculated to be about 1 atom of iodine per 300 pilin subunits. ${ }^{125}$ I-labelled pili behaved identically to normal pili on SDS-PAGE and showed a single band on staining with Kenacid blue R (BDH) and by autoradiography.

Determination of pilus attachment. The methods used were essentially those of Lambden et al. (1980). Buccal epithelial cells and erythrocytes were collected from volunteers and washed several times in PBS. Cells were finally resuspended at a packed cell volume of $5 \%$ in attachment buffer, which consisted of Tris/acetate $(50 \mathrm{~mm})$ containing $\mathrm{NaCl}(140 \mathrm{mM}), \mathrm{CaCl}_{2}(5 \mathrm{mM}), \mathrm{KCl}(4 \mathrm{mM}), \mathrm{MgCl}_{2}(2 \mathrm{mM})$ and bovine serum albumin $\left(1 \mathrm{mg} \mathrm{ml}^{-1}\right)$. The attachment buffer was adjusted to the desired $\mathrm{pH}$ by addition of either Tris $(1 \mathrm{M})$ or acetic acid. The attachment mixture contained $400 \mu \mathrm{l}$ of cell suspension and 1 to $3 \mu \mathrm{g}$ of ${ }^{125}$ I-labelled pili (approx. 20000 c.p.s.) in a final volume of $600 \mu \mathrm{l}$. The mixtures were incubated at $37^{\circ} \mathrm{C}$ for $2 \mathrm{~h}$ with gentle mixing, and then cells were separated from unattached pili by low-speed centrifugation $(100 \mathrm{~g}$ for $1 \mathrm{~min})$ on cushions of dextran (Dextraven 110; Fisons, Loughborough). The dextran layer containing unattached pili was aspirated from the pellet of cells and the amount of bound pili in the pellet was determined by gamma counting. Controls containing pili alone were run for each $\mathrm{pH}$ tested and the number of counts in control tubes were subtracted from the tests. Results were expressed as the percentage of pili recovered from the total added. In one experiment, ten replicate tests of $\alpha$ pilus binding to buccal epithelial cells gave a mean value of $23 \%$ with a standard deviation of $1.4 \%$ and using $\beta$ pili a mean value of $9 \%$ with a standard deviation of $0.8 \%$. 
Attachment of gonococci to alkyl-substituted hydrophobic agarose gels (Miles Laboratories, Stoke Poges, Slough) and ion-exchange agarose gels (Bio-Rad Laboratories) was determined in the same way as attachment to cells, using $20 \%(\mathrm{v} / \mathrm{v})$ gel suspensions in attachment buffer $\mathrm{pH} 6.5$.

Peptide mapping. Two-dimensional peptide mapping after tryptic hydrolysis of $\alpha$ and $\beta$ pili was performed essentially as described by Bates et al. (1975). Freeze-dried pili were dissolved ( $1 \mathrm{mg} \mathrm{ml}^{-1}$, final concentration) in a dissociating buffer containing $0.5 \mathrm{M}$-Tris, $6 \mathrm{M}$-guanidine. $\mathrm{HCl}, 25 \mathrm{mM}-\mathrm{Na}_{2}$ EDTA and $10 \mathrm{~mm}$-2-mercaptoethanol at $\mathrm{pH} 8 \cdot 3$. The solution of denatured pili was flushed with nitrogen and stirred for $2 \mathrm{~h}$ at $37^{\circ} \mathrm{C}$. The pili were then carboxymethylated by the addition of iodoacetic acid $\left(5 \mathrm{mg} \mathrm{ml}^{-1}\right.$, final concentration) followed by incubation in the dark for $2 \mathrm{~h}$ at room temperature. The reaction was stopped by the addition of $50 \mu \mathrm{l}$ of 2 -mercaptoethanol and the pili were dialysed exhaustively against $50 \mathrm{~mm}-\mathrm{NH}_{4} \mathrm{HCO}_{3} \mathrm{pH} 8$, freeze-dried and resuspended at a concentration of $2 \mathrm{mg} \mathrm{ml}^{-1}$ in $50 \mathrm{mM}-\mathrm{NH}_{4} \mathrm{HCO}_{3}$. Trypsin (EC 3.4.21.4; Sigma Type III) was added to give a trypsin to pilus ratio of $1: 100(\mathrm{w} / \mathrm{w})$ and the mixture was incubated at $37^{\circ} \mathrm{C}$ for $6 \mathrm{~h}$. Any insoluble material remaining after tryptic digestion was removed by centrifugation and the soluble material was freeze-dried before dissolving at the required concentration in $50 \mathrm{~mm}-\mathrm{NH}_{4} \mathrm{OH}$. Samples of the tryptic digest were spotted on silica gel thin-layer chromatography plates $(10 \times 10 \mathrm{~cm}$; Polygram Sil G, Camlab, Cambridge). Peptides were resolved by electrophoresis ( $250 \mathrm{~V}$ for $45 \mathrm{~min}$ ) at pH 3.5 (pyridine/acetic acid/water; $1: 10: 189$, by vol.) in the first dimension followed by chromatography ( $n$-butanol/pyridine/acetic acid/water; 15:10:3:12, by vol.) in the second dimension. After chromatography the plates were dried and sprayed either with ninhydrin $(0.25 \%$, w/v) in acetone or with ninhydrin-cadmium reagent (Niederwieser, 1972), i.e. $0 \cdot 2 \%(\mathrm{w} / \mathrm{v})$ ninhydrin in acetone/acetic acid/water ( $43: 2: 5$, by vol.) containing $0 \cdot 1 \%(\mathrm{w} / \mathrm{v})$ cadmium acetate.

Amino acid analysis. Samples ( 25 to $100 \mu \mathrm{g}$ protein) of purified pili were dialysed against distilled water and hydrolysed under vacuum in $6 \mathrm{M}-\mathrm{HCl}$ for $16 \mathrm{~h}$ at $107^{\circ} \mathrm{C}$. Tryptophan was determined by hydrolysis under vacuum in $3 \mathrm{M}$-mercaptoethanesulphonic acid (Penke et al., 1974) for $24 \mathrm{~h}$ at $110^{\circ} \mathrm{C}$. Mercaptoethanesulphonic acid hydrolysates were neutralized with $1 \mathrm{M}-\mathrm{NaOH}$ prior to chromatography. Amino acid analyses were performed on a Rank Hilger Chromaspek amino acid analyser. Amino acid recoveries were corrected for by parallel hydrolyses of purified egg white lysozyme. The overall amino acid composition was determined from several independent hydrolyses.

Buoyant density measurements. Highly purified $\alpha$ or $\beta$ pili $(200 \mu \mathrm{g})$ were homogenized in $10 \mathrm{mM}-\mathrm{Tris} / \mathrm{HCl} \mathrm{pH}$ 8.0 containing $32 \%(\mathrm{w} / \mathrm{w}) \mathrm{CsCl}$ and centrifuged at $72000 \mathrm{~g}$ for $72 \mathrm{~h}$ at $20^{\circ} \mathrm{C}$. Gradients were sampled and the buoyant densities were calculated from refractive index measurements.

Isoelectric focusing. The isoelectric points of $\alpha$ and $\beta$ pili were determined essentially as described by Robertson et al. (1977). Samples $(10$ to $20 \mu \mathrm{g})$ of ${ }^{125}$ I-labelled pili were focused in a $20 \mathrm{ml}$ column containing a 5 to $50 \%$ $(\mathrm{w} / \mathrm{v})$ sucrose gradient and $2.5 \%(\mathrm{v} / \mathrm{v})$ ampholines (an equal mixture of ampholines pH 4.0 to 6.0 and $\mathrm{pH} 6.0$ to $8.0 ;$ LKB). Pili were incorporated into the $5 \%$ sucrose solution prior to gradient formation. A pH gradient was generated by applying a constant potential of $500 \mathrm{~V}$ for $16 \mathrm{~h}$ and the column was cooled to $5{ }^{\circ} \mathrm{C}$ throughout the run. In all experiments myoglobin $(1 \mathrm{mg})$ was added as a visual marker and as an internal standard of known isoelectric point.

Electron microscopy. Gonococci from plates were gently suspended in PBS and 1 to $2 \mu$ drops of the suspension were allowed to stand on Formvar-carbon grids for 1 to $2 \mathrm{~min}$. The excess suspension was removed and the remaining sample was negatively stained by addition of an equivalent volume of $1 \%(\mathrm{w} / \mathrm{v})$ uranyl acetate $\mathrm{pH} 4$.5. After a further 1 to $2 \mathrm{~min}$, the excess uranyl acetate was removed and the grids were dried in air before examination with a Philips EM300 electron microscope.

\section{RESULTS}

Gonococcal $\alpha$ and $\beta$ pili were purified from variants P9-2 and P9-20, respectively. Small differences in the behaviour of the pili were noted during the purification process; for example, $\alpha$ pili aggregated into crystalline bundles at neutral $\mathrm{pH}$ in $0.15 \mathrm{M}-\mathrm{NaCl}$ whereas $\beta$ pili remained disaggregated as individual pili. Also, a greater yield of pili was always obtained from variant P9-2; during a typical pilus preparation about $2 \mathrm{mg}$ of $\alpha$ pili were obtained from $1 \mathrm{~g}$ wet wt of organisms, whereas the yield of $\beta$ pili was usually one-tenth of this. Striking differences in the structure and distribution of pili on whole organisms were seen in electron micrographs of negatively stained gonococci (Fig. 1). The $\alpha$ pili were in large aggregated bundles and appeared to be produced from a few widely-spaced sites on the gonococcal surface. By contrast, $\beta$ pili were well separated, somewhat wavy structures which appeared to radiate outwards over the whole surface of the organism. 

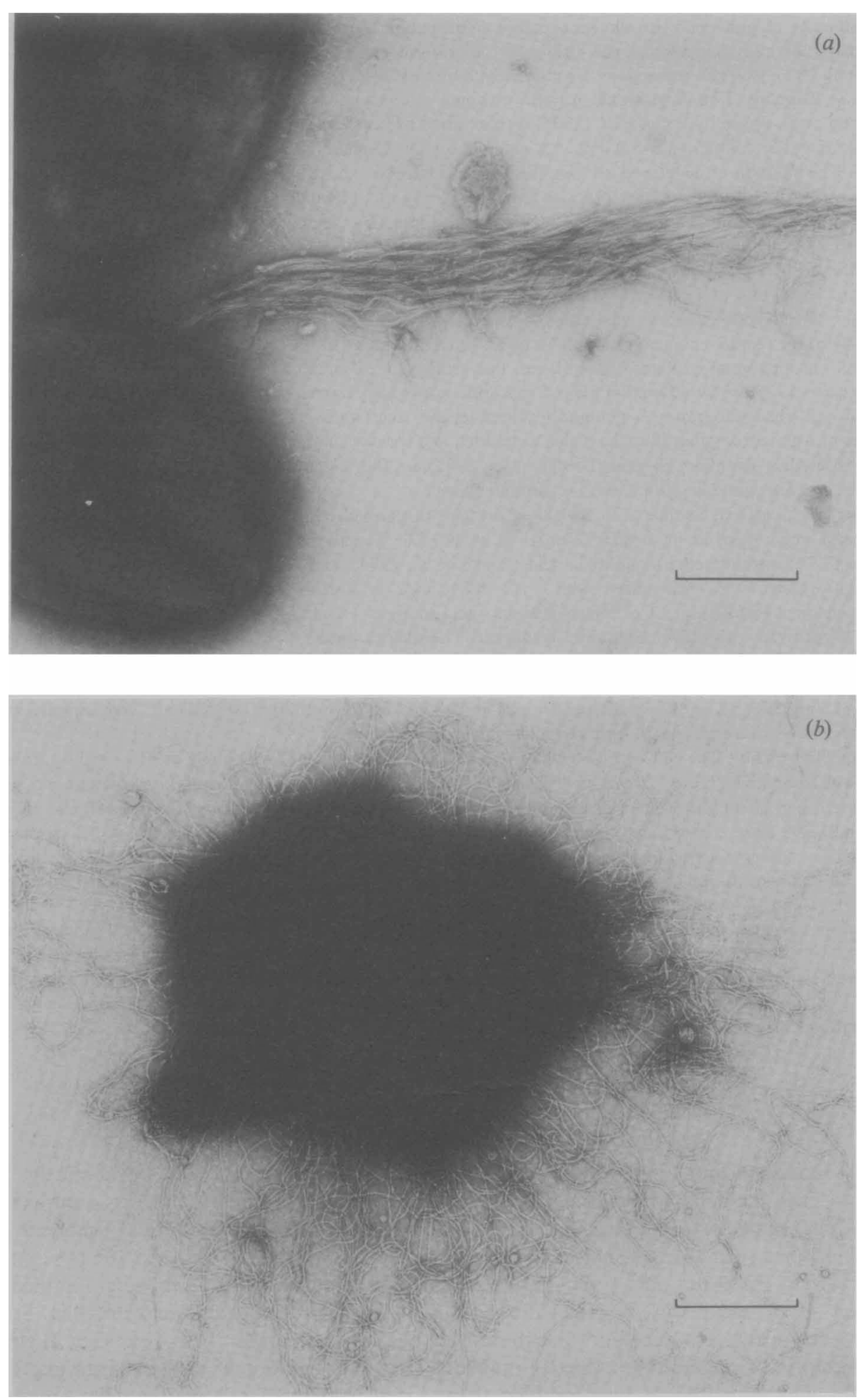

Fig. 1. Electron micrographs showing the appearance and distribution of gonococcal $\alpha$ pili $(a)$ and $\beta$ pili (b). The bar markers represent $1 \mu \mathrm{m}$. 


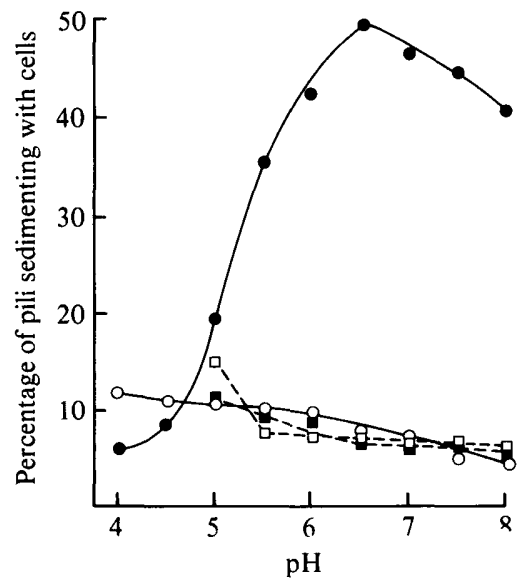

Fig. 2. Effect of $\mathrm{pH}$ on the attachment of ${ }^{125} \mathrm{I}$-labelled $\alpha$ and $\beta$ pili to human buccal epithelial cells (O, $\alpha$ pili; $O, \beta$ pili) and erythrocytes ( $\boldsymbol{\square}, \alpha$ pili; $\square, \beta$ pili).

Table 1. Comparison of the ability of ${ }^{125}$ I-labelled $\alpha$ and $\beta$ pili to bind to DEAE-agarose and to alkyl-substituted hydrophobic agarose gels

\begin{tabular}{|c|c|c|c|c|c|c|c|c|c|c|c|}
\hline \multirow{2}{*}{$\begin{array}{l}\text { Pilus } \\
\text { type }\end{array}$} & \multirow[b]{2}{*}{ pH... } & \multicolumn{5}{|c|}{ Binding (\%) to DEAE-agarose } & \multicolumn{5}{|c|}{ Binding (\%) to alkyl-agarose* } \\
\hline & & $3 \cdot 5$ & $4 \cdot 5$ & $5 \cdot 5$ & $6 \cdot 5$ & $7 \cdot 5$ & $\mathrm{C}-2$ & C-4 & C-6 & C-8 & C -10 \\
\hline$\alpha$ & & $1 \cdot 6$ & $3 \cdot 5$ & $5 \cdot 0$ & 3.4 & $3 \cdot 5$ & 19 & 23 & 47 & 67 & 72 \\
\hline$\beta$ & & 1.4 & 3.2 & 20.0 & 18.5 & $14 \cdot 2$ & 15 & 14 & 53 & 67 & 79 \\
\hline
\end{tabular}

* C-2, ethyl-agarose; C-4, butyl-agarose; C-6, hexyl-agarose; C-8, octyl-agarose; C-10, decyl-agarose.

Antigenic differences between $\alpha$ and $\beta$ pili were clearly demonstrated with antisera raised against purified $\alpha$ or $\beta$ pili in guinea-pigs. Agglutination titres of $1 / 12800$ and $1 / 6400$ were found for homologous $\alpha$ and $\beta$ pili, respectively, and cross-reacting antibodies were not detected at the lowest dilution of antiserum used (1/40). Antisera raised in rabbits were of higher titre to homologous pili $(1 / 25600$ for both $\alpha$ and $\beta$ antisera) but shared weak cross-reactivity with heterologous pili (1/80 for both $\alpha$ and $\beta$ antisera).

Preparations of ${ }^{125}$ I-labelled pili were tested for their ability to bind to human buccal epithelial cells and erythrocytes. Again, striking differences were seen both in the ability of $\alpha$ and $\beta$ pili to attach to these cells and in the response towards the two types of cell (Fig. 2). The attachment of $\alpha$ pili to buccal epithelial cells was markedly $\mathrm{pH}$ dependent with a maximum of $49 \%$ at $\mathrm{pH} 6.5$, whereas the attachment of $\beta$ pili to buccal epithelial cells showed a steady decline over the $\mathrm{pH}$ range tested with a maximum of $12 \%$ at $\mathrm{pH} 4.0$, falling to $5 \%$ at $\mathrm{pH} 8 \cdot 0$. No difference was observed between $\alpha$ and $\beta$ pili in their ability to bind to erythrocytes over the range pH 5.0 to 8.0. Indeed, the extent of binding of both $\alpha$ and $\beta$ pili to erythrocytes was similar to that obtained for $\beta$ pili binding to buccal epithelial cells.

The effect of non-specific interactions on the adhesive mechanism of gonococcal pili was examined by testing the ability of $\alpha$ and $\beta$ pili to bind to alkyl-substituted hydrophobic agarose gels and to DEAE-agarose (Bio-gel A). Binding to alkyl-substituted gels (Table 1) demonstrated that $\alpha$ and $\beta$ pili were not significantly different in their ability to attach through non-specific hydrophobic interactions. However, the two kinds of pili showed clear differences in their ability to bind to DEAE-agarose (Table 1). The binding of both pilus types was $\mathrm{pH}$ dependent and reached a maximum around $\mathrm{pH} 5 \cdot 5$, but $\beta$ pili showed a fourfold greater binding activity. 


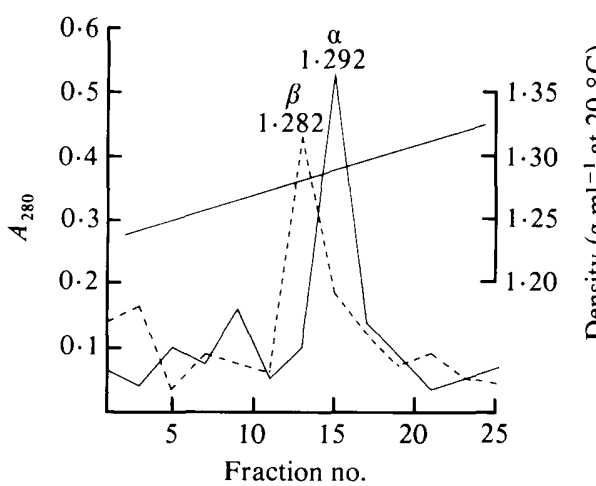

Fig. 3

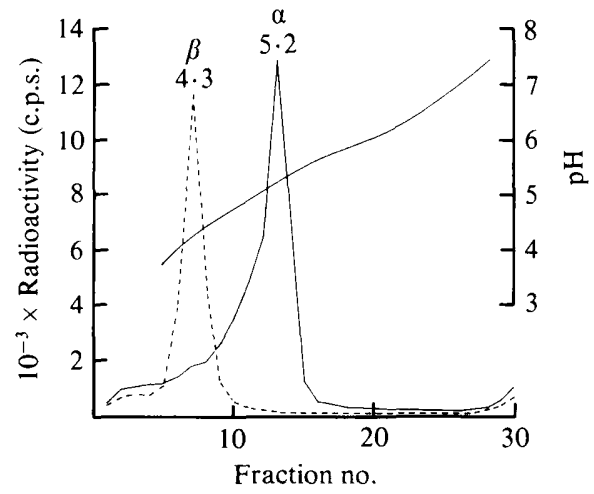

Fig. 4

Fig. 3. Caesium chloride density gradient centrifugation determination of the buoyant density of $\alpha$ and $\beta$ pili. Two independent analyses are shown superimposed on the same graph.

Fig. 4. Isoelectric focusing of $\alpha$ and $\beta$ pili. Small quantities ( 10 to $20 \mu \mathrm{g}$ ) of ${ }^{125}$ I-labelled pili were focused on a sucrose gradient column as detailed in Methods. Two independent analyses are shown superimposed on the same graph.

Gonococcal $\alpha$ and $\beta$ pili exhibited differences in other physico-chemical properties. Centrifugation on a $\mathrm{CsCl}$ gradient revealed that $\alpha$ and $\beta$ pili had different buoyant densities (Fig. 3). Both types of pili formed sharp bands with densities of $1.292 \mathrm{~g} \mathrm{ml}^{-1}$ for $\alpha$ pili and $1.282 \mathrm{~g} \mathrm{ml}^{-1}$ for $\beta$ pili. Further differences were seen after equilibrium electrofocusing (Fig. 4). In order to overcome precipitation problems resulting from the marked aggregation of pili at their isoelectric point, very small quantities of ${ }^{125} \mathrm{I}$-labelled pili were used for the precise determination of $\mathrm{pI}$ values. Further, the use of 10 to $20 \mu \mathrm{g}$ of ${ }^{125} \mathrm{I}$-labelled pili overcame the problem of the pili sticking to the electrofocusing column during fractionation of the $\mathrm{pH}$ gradient and made the detection of the pilus fractions in the presence of ampholines much simpler. Preliminary experiments had demonstrated that ${ }^{125} \mathrm{I}$-labelled pili focused at the same $\mathrm{pH}$ as native unlabelled pili. The isoelectric points for $\alpha$ and $\beta$ pili were pI 5.2 and $\mathrm{pI} 4.3$, respectively. Attempts to resolve mixtures of $\alpha$ and $\beta$ pili proved unsuccessful. This may have been due to formation of hybrid aggregates of pili.

The amino acid composition of $\alpha$ and $\beta$ pili is shown in Table 2. The analysis for the two types of pili showed that they were similar in overall composition. A total of 182.5 residues for a subunit molecular weight of 19500 were obtained for $\alpha$ pili and 188.5 residues for a subunit molecular weight of 20500 were obtained for $\beta$ pili. The percentage of non-polar amino acids (Gly, Ala, Met, Val, Leu, Ile, Phe, Tyr and Trp) was $43 \%$ for $\alpha$ pili and $45 \%$ for $\beta$ pili. Although the two types of pili were similar in their amino acid composition, there were some notable differences. The content of alanine and glutamate/glutamine was greater in $\beta$ pili than in $\alpha$ pili, the $\beta$ pili having seven extra alanine residues and three extra glutamate/glutamine residues. Other, probably less significant, differences were detected: $\alpha$ pili contained one extra residue each of phenylalanine and histidine, and $\beta$ pili contained an extra proline residue.

Further evidence for extensive structural homology between $\alpha$ and $\beta$ pili came from peptide mapping studies using tryptic hydrolysates of $S$-carboxymethylated pili (Fig. 5). The trypsin used in these studies did not incorporate a chymotrypsin inhibitor as qualitative differences rather than structural analyses were required. The diagrammatic representation of the peptide maps (Fig. 5) was compiled from 20 independent analyses of two separately hydrolysed samples of each pilus type. The pili share some 25 peptides (cross-hatched spots in Fig. 5) and possess a smaller number of unique peptides (open spots in Fig. 5). 
Table 2. Amino acid composition of Neisseria gonorrhoeae P9 pili

$\begin{array}{lcc}\text { Amino acid } & \begin{array}{c}\alpha \text { pili: } \\ \text { residues/ } \\ 19500 \text { mol. wt }\end{array} & \begin{array}{c}\beta \text { pili: } \\ \text { residues/ } \\ 20500 \text { mol. }\end{array} \\ \text { Asx* } & 24 & 25 \\ \text { Thr } & 14 & 12 \\ \text { Ser } & 17 & 15 \\ \text { Gl* } & 15 & 18 \\ \text { Pro } & 5 & 6 \\ \text { Gly } & 13 & 13 \\ \text { Ala } & 20 & 27 \\ \text { Cys/2 } & 6 & 6 \\ \text { Val } & 16 & 16 \\ \text { Met } & 1.5 & 1 \cdot 5 \\ \text { Ile } & 7 & 7 \\ \text { Leu } & 9 & 9 \\ \text { Tyr } & 6 & 6 \\ \text { Phe } & 3 & 2 \\ \text { His } & 2 & 1 \\ \text { Trp } & 4 & 4 \\ \text { Lys } & 15 & 5 \\ \text { Arg } & 5 & \end{array}$

* Asx, Aspartic acid or asparagine; Glx, glutamic acid or glutamine.

$\alpha$ pili
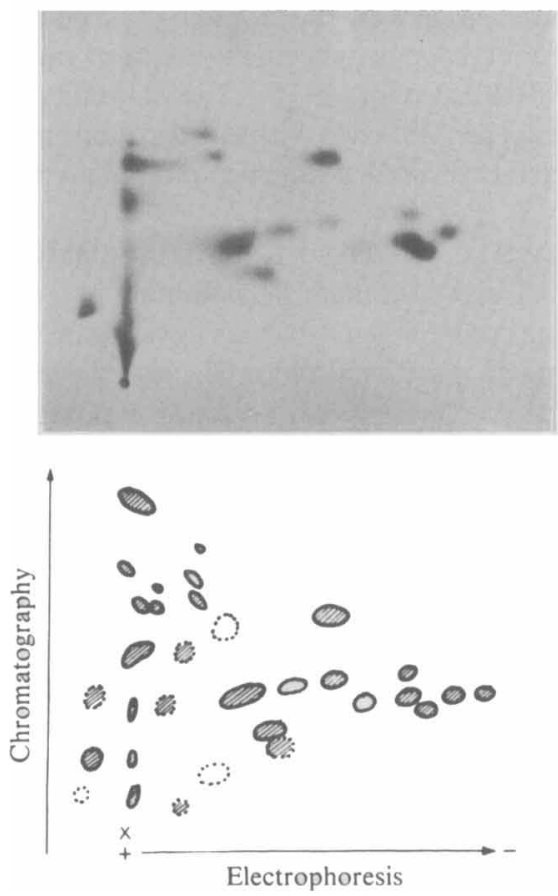

$\beta$ pili
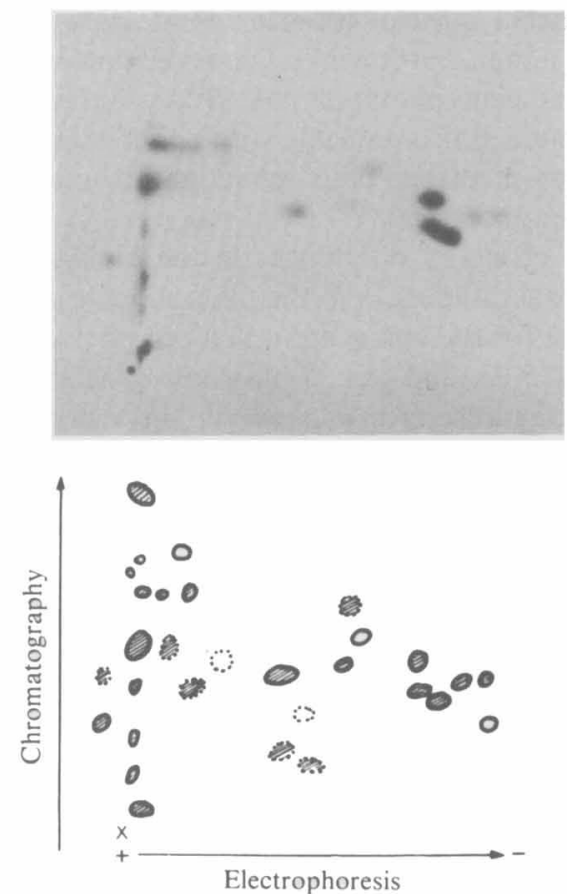

Fig. 5. Two-dimensional peptide mapping of tryptic hydrolysates of $\alpha$ and $\beta$ pili on silica gel thin-layer plates, developed in the first dimension by electrophoresis and in the second dimension by chromatography. Top: ninhydrin-sprayed plates showing major peptides. Bottom: diagrammatic representation of peptide maps. Maps for each pilus type were drawn from a compilation of 20 separate experiments. Major spots are drawn with a continuous boundary and minor or faint spots are drawn with a dotted boundary. Spots for peptides common to both $\alpha$ and $\beta$ pili are cross-hatched and open spots represent unique peptides. 
DIS C USSION

Neisseria gonorrhoeae colonizing mucosal surfaces must survive in a complex unstable environment which effects changes in the phenotypic expression of certain gonococcal surface proteins (James \& Swanson, 1978). For instance, gonococci are exposed to extremes of $\mathrm{pH}$ varying from $\mathrm{pH} 7.19$ in semen and $\mathrm{pH} 6.45$ in prostatic secretion to a range of $\mathrm{pH}$ 4.8 to 8.0 in urine. During the menstrual cycle the $\mathrm{pH}$ of endocervical mucus varies from $\mathrm{pH}$ 5.9 to 7.3 , of ectocervical mucus from $\mathrm{pH} 4.0$ to 7.4 and in the vagina from $\mathrm{pH} 3.5$ to 5.8 (Kroeks \& Kremer, 1977). It was noteworthy that over the $\mathrm{pH}$ range tested, $\alpha$ and $\beta$ pili differed in their ability to bind to buccal epithelial cells. The binding of $\alpha$ pili to buccal epithelial cells was markedly $\mathrm{pH}$ dependent with a maximum binding between $\mathrm{pH} 6$ and 7 , the optimal $\mathrm{pH}$ for growth at the preferred sites of infection at the endocervix and male urethra. Interestingly, the attachment of $\alpha$ pili to erythrocytes showed no $\mathrm{pH}$ optimum but rather a steady decline with increasing $\mathrm{pH}$, suggesting that these cells differ from buccal cells in lacking a specific binding site for $\alpha$ pili. Further, the absence of a $\mathrm{pH}$ optimum for $\alpha$ pili binding to erythrocytes indicates that pilus-pilus interactions around the isoelectric point do not account for the observed $\mathrm{pH}$ dependence of $\alpha$ pilus attachment to buccal epithelial cells. The simplest explanation for the finding that $\beta$ pilus adhesion shows no $\mathrm{pH}$ optimum but increases gradually with increasing $\mathrm{pH}$ is that $\beta$ pili lack receptor recognition for buccal epithelial cells. However, the fact that below $\mathrm{pH} \mathrm{5.0} \beta$ pilus adhesion to epithelial cells exceeded that of $\alpha$ pili may be of significance during colonization of the vagina at low $\mathrm{pH}$. Variation in the type of pilus produced by single strains of gonococci according to the site of colonization may have important implications in the search for a gonococcal vaccine. Although preliminary studies (Brinton et al., 1978) suggest that immunization with gonococcal pili can protect volunteers against challenge with the homologous gonococcal strain, a major problem in the development of an effective pilus vaccine is the large number of different pilus immunotypes (Brinton et al., 1978; Buchanan, 1975). This difficulty will be compounded if organisms with either $\alpha$ or $\beta$ pilus types are each virulent for man, since the antibody-mediated pilus agglutinations clearly demonstrated antigenic differences between the two types of pili.

The observed differences in the biological properties of $\alpha$ and $\beta$ pili presumably reflect structural differences in the pilus subunit protein. A higher content of glutamate in $\beta$ pili may account for the observation that the isoelectric point of $\beta$ pili (pI 4.3) was lower than that of $\alpha$ pili (pI 5.2), and that $\beta$ pili show greater binding to positively charged groups present on DEAE-agarose. An increase in the number of acidic amino-acid residues exposed at the surface of $\beta$ pili could impair binding to the negatively charged host cell surface. Certainly a role for pili in penetrating the electrostatic repulsive barrier between the gonococcus and host cell surfaces has been demonstrated in tissue culture systems (Heckels et al., 1976). Despite differences in the content of alanine and glutamate/glutamine, $\alpha$ and $\beta$ pili showed close overall similarity in amino acid composition. Further evidence for a high degree of structural homology was seen from the peptide maps, which showed at least 20 common tryptic peptides, and some unique peptides which presumably reflect the basic structural differences between $\alpha$ and $\beta$ pili.

The genetic basis for the phenotypic change from $\alpha$ to $\beta$ pili is at present unknown. One possibility is that both types of pili are derived from a single structural gene and that post-translational modification results in two alternative pilin subunits. For example, modification of the subunit of $\beta$ pili, by cleavage of a fragment rich in alanine and glutamate, could give rise to the lower molecular weight subunit of $\alpha$ pilin. An alternative possibility is that these two pilus forms are coded for by separate structural genes, the expression of which is controlled by a mechanism analogous to that found in the regulation of flagellar phase variation in Salmonella (Kutsukake \& Iino, 1980). The high degree of structural homology between the two forms of pili may be the result of a gene duplication event together with mutational alteration of one or both sequences. The true situation must await a full genetic 
analysis of this system, perhaps using the powerful techniques of gene cloning and DNA sequencing.

This work was supported by a Medical Research Council Programme Grant.

\section{REFERENCES}

Bates, D. L., Perham, R. N. \& Coggins, J. R. (1975). Methods for obtaining peptide maps of proteins on a subnanomole scale. Analytical Biochemistry 68, 175-184.

Brinton, C. C., Bryan, J., Dillon, J.-A., Guerina, N., Jacobson, L. J., LABIK, A., LeE, S., Levine, A., Lim, S., McMichael, J., Polen, S., Rogers, K., To, A. C.-C. \& To, S. C.-M. (1978). Uses of pili in gonorrhoea control: role of bacterial pili in disease, purification and properties of gonococcal pili, and progress in the development of a gonococcal pilus vaccine for gonorrhoea. In Immunobiology of Neisseria gonorrhoeae, pp. 155-178. Edited by G. F. Brooks, E. C. Gotschlich, K. K. Holmes, W. D. Sawyer \& F. E. Young. Washington, D.C.: American Society for Microbiology.

BUCHANAN, T. M. (1975). Antigenic heterogeneity of gonococcal pili. Journal of Experimental Medicine 141, 1470-1475.

Buchanan, T. M., Chen, K. C. S., Jones, R. B., Hildebrandt, J. F., Pearce, W. A., Hermodson, M. A., Newland, J. C. \& LuChTEl, D. L. (1978). Pili and principal outer membrane protein of Neisseria gonorrhoeae: immunochemical, structural and pathogenic aspects. In Immunobiology of Neisseria gonorrhoeae, pp. 145-154. Edited by G. F. Brooks, E. C. Gotschlich, K. K. Holmes, W. D. Sawyer \& F. E. Young. Washington, D.C.: American Society for Microbiology.

Dilworth, J. A., Hendley, J. O. \& Mandell, G. L. (1975). Attachment and ingestion of gonococci by human neutrophils. Infection and Immunity 11, 512-516.

Greenwood, F. C., Hunter, W. M. \& Glover, J. S. (1963). The preparation of ${ }^{131}$ I-labelled human growth hormone of high specific radioactivity. Biochemical Journal 89, 114-123.

Heckels, J. E., Blackett, B., Everson, J. S. \& WARD, M. E. (1976). The influence of surface charge on the attachment of Neisseria gonorrhoeae to human cells. Journal of General Microbiology 96 , 359-364.

James, J. F. \& Swanson, J. (1978). Color/opacity colonial variants of Neisseria gonorrhoeae and their relationship to the menstrual cycle. In Immunobiology of Neisseria gonorrhoeae, pp. 338-343. Edited by G. F. Brooks, E. C. Gotschlich, K. K. Holmes, W. D. Sawyer \& F. E. Young. Washington, D. C.: American Society for Microbiology.

James, A. N., Knox, J. M. \& Williams, R. P. (1976). Attachment of gonococci to sperm. Influence of physical and chemical factors. British Journal of Venereal Diseases 52, 129-135.
Jephcott, A. E., Reyn, A. \& Birch-Anderson, A. (1971). Neisseria gonorrhoeae III. Demonstration of presumed appendages to cells from different colony types. Acta pathologica et microbiologica scandinavica B79, 437-439.

Kroeks, M. V. A. M. \& Kremer, J. (1977). The $\mathrm{pH}$ in the lower third of the genital tract. In The Uterine Cervix in Reproduction, pp. 109-117. Edited by V. Insler \& G. Bettendorf. Stuttgart: Thieme.

KutsukAKe, K. \& IINO, T. (1980). A trans-acting factor mediates inversion of a specific DNA segment in flagellar phase variation of Salmonella. Nature, London 284, 479-481.

Lambden, P. R., Heckels, J. E., James, L. T. \& WATT, P. J. (1979). Variations in surface protein composition associated with virulence properties in opacity types of Neisseria gonorrhoeae. Journal of General Microbiology 114, 305-312.

Lambden, P. R., Robertson, J. N. \& Watt, P. J. (1980). Biological properties of two distinct pilus types produced by isogenic variants of Neisseria gonorrhoeae P9. Journal of Bacteriology 141, 393-396.

Niederwieser, A. (1972). Thin-layer chromatography of amino acids and derivatives. Methods in Enzymology 25B, 60-99.

Ofek, I., BeAchey, E. H. \& Bisno, A. L. (1974). Resistance of Neisseria gonorrhoeae to phagocytosis: relationship to colonial morphology and surface pili. Journal of Infectious Diseases 129, 310-316.

Penke, B., Ferenczi, R. \& Kovacs, K. (1974). A new acid hydrolysis method for determining tryptophan in peptides and proteins. Analytical Biochemistry $\mathbf{6 0}$, 45-50.

Robertson, J. N., Vincent, P. \& WARD, M. E. (1977). The preparation and properties of gonococcal pili. Journal of General Microbiology 102 , 169-177.

Salit, I. E., Blake, M. \& Gotschlich, E. C. (1980). Intrastrain heterogeneity of gonococcal pili is related to opacity colony variance. Journal of Experimental Medicine 151, 716-725.

Swanson, J. (1973). Studies on gonococcus infection. IV. Pili: their role in attachment of gonococci to tissue culture cells. Journal of Experimental Medicine 137, 571-589.

Swanson, J., Kraus, S. J. \& Gotschlich, E. C. (1971). Studies on gonococcus infection. I. Pili and zones of adhesion: their relation to gonococcal growth patterns. Journal of Experimental Medicine 134, 886-906. 